\title{
Do denture teeth dimensions match natural anterior teeth?
}

\section{As dimensões dos dentes artificiais correspondem aos dentes anteriores naturais?}

\author{
Ricardo Guimarães NEVES 1,2 iD https://orcid.org/0000-0003-0415-2645 \\ Dhiogo Ribeiro de SOUZA2 ID https://orcid.org/0000-0002-9271-5702 \\ Mariana Rodrigues Gil DAHER ${ }^{2}$ iD https://orcid.org/0000-0001-9951-6338 \\ Victor Hugo Rocha LIMA2 iD https://orcid.org/0000-0002-3287-5237 \\ Érica Miranda de TORRES ${ }^{2}$ iD https://orcid.org/0000-0002-5544-6865
}

\begin{abstract}
Objective: To compare dimensions of natural maxillary anterior teeth and several denture teeth molds and also address differences between genders. Methods: A single examiner with a digital caliper measured dental casts of 41 males and 55 females in order to determine CIW (central incisor width), CIL (central incisor length) and WS (width of anterior teeth on a straight line). In addition, WC (width of anterior teeth on a curve) was measured with a flexible ruler. These parameters were also observed on three denture teeth mold charts: Premium Pala, Vivodent and Trilux. The comparison between genders was analyzed using Student's t-test ( $\mathrm{a}=.05$ ), while absolute frequencies within several ranges were used to compare natural and denture teeth. Results: CIW, CIL, WS and WC obtained from males were significantly higher than those found for females $(p<0.05)$. CIW of nearly half of natural and denture teeth were within 8.0-8.5 mm. Almost half of natural teeth presented CIL values within 10.6-11 mm, while the highest frequency of denture teeth was observed within 9.6-10 mm. The majority of natural and denture teeth presented WS values within 42 to 49 mm. Only one denture teeth chart described WC values, which were mainly observed within 44-51 mm, while the majority of WC values obtained from natural teeth ranged from 48 to $55 \mathrm{~mm}$. Conclusion: Some commercially available denture teeth present dimensions not observed in natural teeth. Teeth dimensions in function of gender differences must be considered when selecting denture teeth.
\end{abstract}

Indexing terms: Dental prosthesis. Esthetics. Tooth, artificial.

\section{RESUMO}

Objetivo: Comparar as dimensões dos dentes anteriores superiores naturais e de diversos dentes artificiais para próteses e também abordar as diferenças entre os gêneros. Métodos: Um único examinador mediu com um paquímetro digital dentes naturais de 41 homens e 55 mulheres para determinar CIW (largura do incisivo central), CIL (comprimento do incisivo central) e WS (largura dos dentes anteriores superiores em linha reta). Adicionalmente, CC (largura dos dentes anteriores em uma curva) foi aferida com uma régua flexível. Esses parâmetros também foram observados em três cartas moldes de dentes artificiais para prótese: Premium Pala, Vivodent e Trilux. A comparação entre os sexos foi analisada pelo teste $t$ de Student $(\alpha=0,05)$, enquanto frequências absolutas foram usadas para comparar medidas dos dentes naturais e artificiais. Resultados: CIW, CIL, WS e WC obtidos de homens foram significativamente

${ }^{1}$ Clínica Privada. Anápolis, GO, Brasil.

2 Universidade Federal de Goiás, Programa de Pós-Graduação em Odontologia. Av. Universitária, s/n., Setor Leste Universitário, 74605-220, Goiânia, GO, Brasil. Correspondence to: EM TORRES. E-mail: torresodonto@ufg.br.

$\boldsymbol{\nabla} \mathbf{v}$

How to cite this article

Neves RG, Souza DR, Daher MRG, Lima VHR, Torres EM. Do denture teeth dimensions match natural anterior teeth?. RGO, Rev Gaúch Odontol. 2020;68: e20200056. http://dx.doi.org/10.1590/1981-863720200005520190085 
maiores do que aqueles encontrados para mulheres $(p<0,05)$. CIW de quase metade de dentes naturais e artificiais estavam entre 8,0-8,5 mm. Quase metade dos dentes naturais apresentaram valores CIL entre 10,6-11 mm, enquanto a maior frequência de dentes artificiais foi observada entre 9,6-10 mm. A maioria dos dentes naturais e artificiais apresentaram valores WS entre 42-49 mm. Apenas uma carta molde de dentes artificiais descreveu os valores de WC, que foram observados principalmente entre 44-51 mm, enquanto a maioria dos valores de WC obtidos em dentes naturais variaram de 48 a $55 \mathrm{~mm}$. Conclusão: Alguns dentes artificiais para próteses disponíveis comercialmente apresentam dimensões não observadas nos dentes naturais. As dimensões dos dentes em função das diferenças de gênero devem ser consideradas na seleção dos dentes artificiais.

Termos de indexação: Prótese dentária. Estética. Dente artificial.

\section{INTRODUCTION}

People that suffered tooth loss usually seek prosthetic rehabilitation; however, its success also results from the harmonious relationship between facial components and oral cavity [1-4]. The reestablishment of orofacial esthetics and function is more difficult to achieve in the absence of preextraction records or previous prosthesis that would guide the selection of denture teeth with appropriate dimensions [5].

The successful selection of anterior teeth sizes relies on dentist's proper scientific knowledge, patient's realistic expectations and commercial availability of assorted sets of denture teeth; therefore, any failure to meet these aspects may even lead to the rejection of comfortable and efficient prostheses manufactured in accordance with functional principles [2].

Whilst the length of the upper lip and the smile line can be used as reliable references to estimate teeth heights, the mesiodistal width figures as a determinant factor for harmony and is more difficult to determine $[6,7]$. Denture tooth width is usually determined by marking the canine locations on the maxillary wax occlusal rim; then, the distance between canines around the rim determines the curve of the six anterior teeth. Nevertheless, several manufacturers of denture teeth provide mold charts with only the measurement of anterior teeth arranged in a straight line [8].

Considering that selecting denture teeth with correct size may be particularly difficult, very few studies investigated the match between natural and commercially available denture in terms of dimensions in order to provide a major support for dentists $[9,10]$. Therefore, the objectives of this study were (1) to compare the dimensions of natural maxillary anterior teeth and several molds of denture teeth and (2) to address differences between genders.

\section{METHODS}

After receiving approval of the study by the Ethics Committee of the Federal University of Goiás (\#248/12), maxillary dental casts of 41 males and 55 females (mean ages of 22.5 and 21.8 years, respectively) were selected in accordance with the inclusion criteria: sound maxillary anterior teeth, Angle Class I occlusion, no crowding or rotations.

A single examiner used a $0.01 \mathrm{~mm}$ digital caliper (ZAAS Precision) to determine the following parameters: mean of the widest mesiodistal portion of central incisors (CIW; figure 1); distance between the most apical point of the cementoenamel junction and the most incisal point of the anatomic crown (CIL; figure 2) [11]; combined width of the six anterior teeth on a straight line (WS; figure 3) [12]; the curve distance between the distal surfaces of canines measured with a 1-mm-grading flexible ruler (RPF-0585, JON, Brazil) placed at the greatest curvature of the arch (WC; figure 4) $[2,10,13]$. These parameters were also observed on three different denture teeth mold charts: Premium Pala (Heraeus Kulzer, Hanau, Germany), SR Vivodent PE (Ivoclar Vivadent, Schaan, Liechtenstein) and Trilux (VIPI, Pirassununga, Brazil).

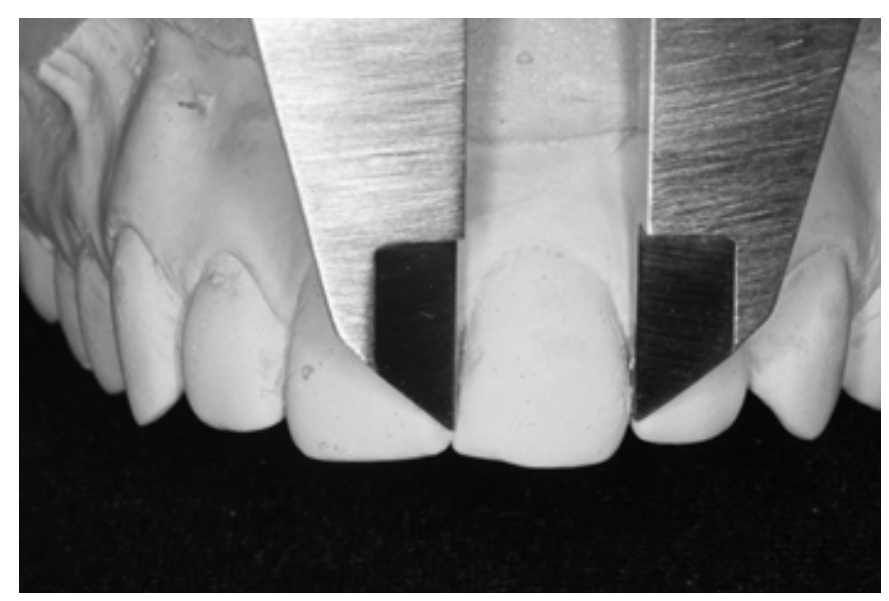

Figure 1. CIW measurement. 
The same examiner repeated all cast measurements after 21 days in order to address intra-examiner reproducibility by means of intraclass correlation coefficient (ICC). The Kolmogorov-Smirnov and Levene's test were used to assess normal distribution of data and homogeneity of variances, respectively. The comparison between genders

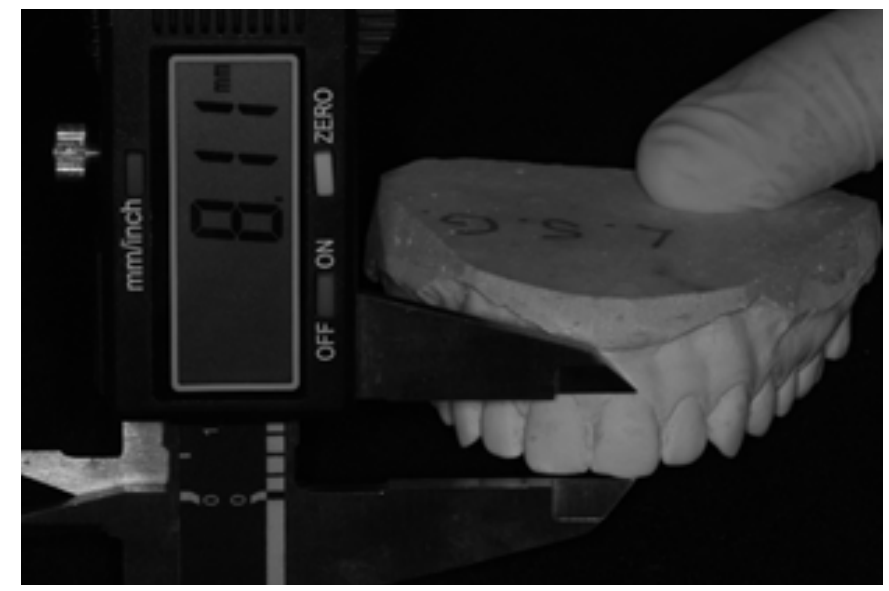

Figure 2. CIL measurement.

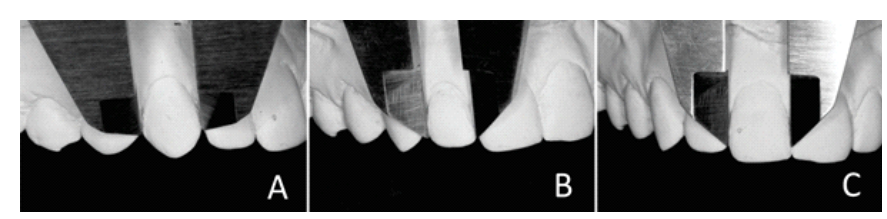

Figure 3. Measurement of all canine (A), lateral incisor (B) and central incisor (C) in order to determine WS.

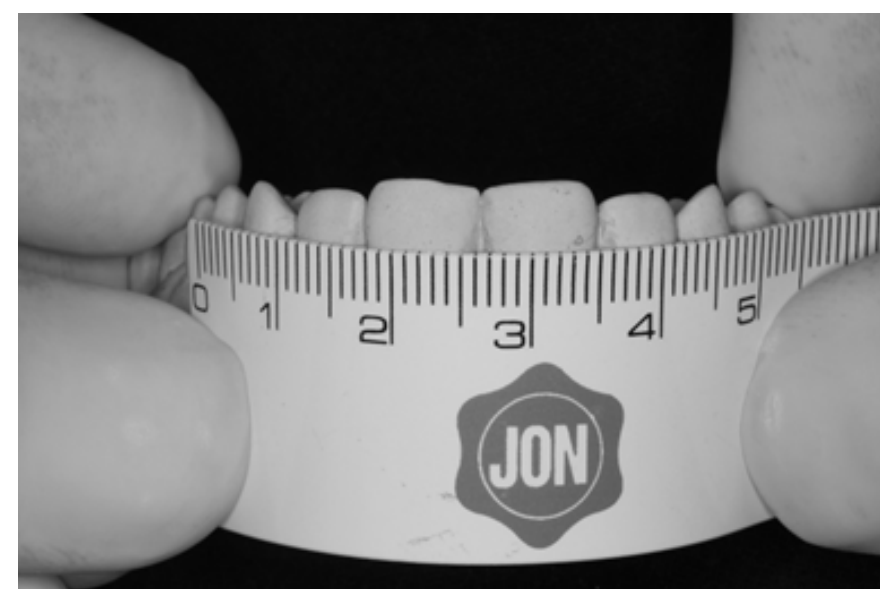

Figure 4. WC measurement. was analyzed using Student's t-test $(\alpha=.05)$. Descriptive analysis of absolute frequencies within several parameter ranges was used to compare natural and denture teeth. All analyses were performed with statistical software (SPSS 21.0, IBM, Armonk, USA).

\section{RESULTS}

The intraclass correlation coefficient indicated excellent intra-examiner reproducibility for all parameters (ICC >.92). All parameters (CIW, CIL, WS and WC) obtained from dental casts of males were significantly higher than those found for females $(p<0.05)$.

CIW values within the ranges $8.0-8.5 \mathrm{~mm}$ for females (49\%) and 8.6-8.9 $\mathrm{mm}$ for males (46\%) accounted for nearly half of the individuals; in addition, the majority of denture teeth molds were also found within the same ranges $8.0-8.5 \mathrm{~mm}(42 \%)$ and $8.6-8.9 \mathrm{~mm}(25 \%)$, although $52 \%$ of Trilux molds presented CIW within 8.6-8.9 $\mathrm{mm}$ (table 1).

Regardless of gender, almost half (43\%) of natural teeth presented CIL values within 10.6-11 mm, followed by $10.1-10.5 \mathrm{~mm}(33 \%)$ and $9.6-10 \mathrm{~mm}(14 \%)$; however, the frequencies of denture teeth molds with CIL values within the same ranges were more similar $(19 \%, 21 \%$ and $31 \%$, respectively). Differently from denture teeth molds, natural teeth with CIL smaller than $8.6 \mathrm{~mm}$ and greater than $12 \mathrm{~mm}$ were not found (table 2).

The majority (85\%) of denture teeth molds also presented WS values within 42 to $49 \mathrm{~mm}$. Similarly, $90 \%$ of natural teeth presented WS values ranging from 42 to $49 \mathrm{~mm}$; however, $81 \%$ of the values obtained from males were concentrated between 46 and $51 \mathrm{~mm}$ while females presented $53 \%$ of the WS values in the same range and $41 \%$ between 42 and $45 \mathrm{~mm}$ (table 3), which suggests that a greater variety of denture teeth molds is more compatible with female teeth dimensions.

Overall, $90 \%$ of WC values obtained from natural teeth ranged from 48 to $55 \mathrm{~mm}$; however, males presented only $17 \%$ of the values ranging from 48 to $55 \mathrm{~mm}$ and $66 \%$ concentrated between 52 and $55 \mathrm{~mm}$ (table 4). On the other hand, females presented $45 \%$ and $50 \%$ of WC values ranging from 48 to $55 \mathrm{~mm}$ and 52 to 55 $\mathrm{mm}$, respectively. WC values were only observed in one mold chart and the majority of molds (70\%) were found 
between 44 and $51 \mathrm{~mm}$, which also better match to female teeth dimensions. Although Trilux also presented molds for
WC ranges of 44-45 $\mathrm{mm}$ and $60-61 \mathrm{~mm}$, no natural teeth were observed in these ranges.

Table 1. Absolute frequencies of natural and denture teeth within CIW ranges.

\begin{tabular}{|c|c|c|c|c|c|c|c|}
\hline \multirow{2}{*}{$\begin{array}{l}\text { CIW } \\
(\mathrm{mm})\end{array}$} & \multicolumn{3}{|c|}{ Natural teeth } & \multicolumn{4}{|c|}{ Denture teeth } \\
\hline & Male & Female & Total & Pala & Vivodent & Trilux & Total \\
\hline $7.0-7.4$ & 0 & 1 & 1 & 0 & 0 & 1 & 1 \\
\hline $8.0-8.5$ & 8 & 27 & 35 & 5 & 6 & 12 & 23 \\
\hline $8.6-8.9$ & 19 & 11 & 30 & 3 & 7 & 4 & 14 \\
\hline $9.6-9.9$ & 3 & 2 & 5 & 1 & 1 & 1 & 3 \\
\hline
\end{tabular}

Table 2. Absolute frequencies of natural and denture teeth within CIL ranges.

\begin{tabular}{|c|c|c|c|c|c|c|c|}
\hline $\mathrm{CIL}(\mathrm{mm})$ & \multicolumn{3}{|c|}{ Natural teeth } & \multicolumn{4}{|c|}{ Denture teeth } \\
\hline $8.0-8.5$ & 0 & 0 & 0 & 0 & 1 & 2 & 3 \\
\hline $8.6-9.0$ & 0 & 1 & 1 & 0 & 1 & 1 & 2 \\
\hline $9.1-9.5$ & 0 & 1 & 1 & 0 & 2 & 3 & 5 \\
\hline $10.6-11.0$ & 21 & 20 & 41 & 3 & 5 & 2 & 10 \\
\hline $11.1-11.5$ & 3 & 3 & 6 & 1 & 0 & 1 & 2 \\
\hline $11.6-12.0$ & 1 & 0 & 1 & 3 & 0 & 0 & 3 \\
\hline
\end{tabular}

Table 3. Absolute frequencies of natural and denture teeth within WS ranges.

\begin{tabular}{|c|c|c|c|c|c|c|c|}
\hline \multirow{2}{*}{$\begin{array}{l}\text { WS } \\
(\mathrm{mm})\end{array}$} & \multicolumn{3}{|c|}{ Natural teeth } & \multicolumn{4}{|c|}{ Denture teeth } \\
\hline & Male & Female & Total & Pala & Vivodent & Trilux & Total \\
\hline $40-41$ & 0 & 2 & 2 & 1 & 1 & 1 & 3 \\
\hline $44-45$ & 4 & 15 & 19 & 3 & 4 & 6 & 13 \\
\hline $46-47$ & 14 & 19 & 33 & 4 & 3 & 7 & 14 \\
\hline $50-51$ & 6 & 1 & 7 & 2 & 0 & 1 & 3 \\
\hline $52-53$ & 1 & 0 & 1 & 0 & 1 & 1 & 2 \\
\hline
\end{tabular}


Table 4. Absolute frequencies of natural and denture teeth within WC ranges.

\begin{tabular}{lcccc}
\hline WC & & Natural teeth & Denture teeth \\
\cline { 2 - 4 } (mm) & Male & Female & Total & Trilux \\
\hline $44-45$ & 0 & 0 & 0 & 3 \\
$46-47$ & 0 & 1 & 1 & 2 \\
$48-49$ & 1 & 8 & 9 & 7 \\
$50-51$ & 6 & 16 & 22 & 0 \\
$52-53$ & 11 & 15 & 29 & 0 \\
$54-55$ & 16 & 13 & 5 & 1 \\
$56-57$ & 4 & 1 & 4 & 0 \\
$58-59$ & 3 & 1 & 0 & 1 \\
\hline
\end{tabular}

Table 5. Mean and standard deviation of each parameter, 95\% confidence interval and P-values for gender comparison.

\begin{tabular}{|c|c|c|c|c|}
\hline Parameter & Gender & Mean $( \pm$ SD $)$ & $95 \% \mathrm{Cl}$ & $P$-value \\
\hline CIW & Female & $8.5( \pm 0.5)$ & $8.4-8.7$ & 0.007 \\
\hline $\mathrm{CIL}$ & Female & $10.4( \pm 0.6)$ & $10.3-10.6$ & 0.006 \\
\hline WS & Male & $47.6( \pm 2.1)$ & $46.9-48.3$ & 0.001 \\
\hline \multirow{2}{*}{ WC } & Male & $53.8( \pm 2.3)$ & $53.1-54.5$ & \multirow{2}{*}{0.001} \\
\hline & Female & $51.9( \pm 2.3)$ & $51.3-52.5$ & \\
\hline
\end{tabular}

\section{DISCUSSION}

This study confirmed that CIW, CIL, WS and WC values obtained from dental casts of males are significantly higher from those observed for females $(p<0.05)$. Among several investigations that corroborate the findings of our study [12-15], Owens et al. [16] reported that natural central incisors of African, American and Hispanic males are significantly larger than those of females. After measuring the width of central and lateral incisors and the anterior teeth combined width of Serbian adults, Strajni et al. [4] also reported significant differences between genders (males > females). However, Condon et al. [17] evaluated the dimensions and ratios of maxillary anterior teeth of dental casts obtained from 109 Irish students aged between 18 and 25 years and found no significant differences between genders. In the same line, Gomes et al. [2] measured WC on dental casts obtained from 81 Brazilian students and found no significant difference between genders.
In this study, CIW mean values registered for males $(8.8 \mathrm{~mm})$ and females $(8.5 \mathrm{~mm})$ were significantly different $(p=0.007)$ (table 5). On the contrary, Gillen et al. [18], measured CIW values on dental casts of 54 individuals and found no significant difference between genders. Moreover, a good match between natural and denture teeth dimensions (three manufacturers and total of 55 molds) was indicated since the majority of CIW values (68\% and $67 \%$, respectively) were observed between 8 to $8.9 \mathrm{~mm}$. Similarly to our findings, Srivastava [1] reported that CIW values of 150 individuals ranged from 7.3 to 10 $\mathrm{mm}$, while denture teeth molds ranged between 7.3 to $9.1 \mathrm{~mm}$.

CIL mean values observed in this study for males $(10.7 \mathrm{~mm})$ and females $(10.4 \mathrm{~mm})$ were significantly different $(p=0.006$ ) (table 5). Gillen et al. [18] also observed significantly different CIL values between males and females for both white and African-American individuals; therefore, population characteristics seem to be also 
important when determining dental dimensions.

A significant difference was found between WS mean values of males $(47.6 \mathrm{~mm})$ and females $(45.6 \mathrm{~mm})$ $(p=0.001)$. Al Wazzan [12] also observed lower WS values for 204 Saudi Arabian females in comparison to 203 males; teeth were intraorally measured with Boley gauge and mean WS values (males $46.1 \mathrm{~mm}$ and females $44.5 \mathrm{~mm}$ ) were similar to our findings. The highest WS frequency for denture teeth was registered for the $46-47 \mathrm{~mm}$ range, followed by $44-45$ and $42-43 \mathrm{~mm}$, which are found more often for females that have lower WS than males. Srivastava [1] also reported WS values after measuring all anterior teeth: $46.25 \mathrm{~mm}$ (41.4 to $52.4 \mathrm{~mm}$ ) for males and 45.1 $\mathrm{mm}$ (39.4 to $51.6 \mathrm{~mm}$ ) for females. Four brands of denture teeth were also evaluated in that study that reported WS mean value of $42.8 \mathrm{~mm}$ (38.4 to $47.6 \mathrm{~mm}$ ) and $39-42 \mathrm{~mm}$ as the most frequent range. Finally, the author concluded that denture anterior teeth is predominantly narrower than natural teeth, which presents WS higher than $45 \mathrm{~mm}$; however, a large number of denture teeth molds presents WS lower than $41 \mathrm{~mm}[1]$.

Males and females presented significant difference regarding WC mean values $(p=0.0001)$ (table 5$)$. WC of anterior teeth is rarely used in dental practice since most manufacturers of denture teeth only indicate WS values [8]; WC was only found on Trilux mold chart. The measurement method with the aid of a 1-mm-grading flexible ruler has also been used by dentists and reported by other studies $[2,10,13]$. After demonstrating a strong correlation between WS and WC, Varjão \& Nogueira [8] used WS values to calculate WC values, which are closer to mean values found in our study $(53.8 \mathrm{~mm}$ for males and $51.9 \mathrm{~mm}$ for females). Baer \& Reynolds [13] obtained WC values from 451 dental casts $(55.6 \mathrm{~mm}$ for males and 53.6 for females) and compared with Bioblend (Dentsply, USA) mold chart; they observed that WC of females match with the most frequent denture teeth molds that were found within 50-54 and 44-49 mm. Mahmood et al. [10] measured WC of 280 dental casts and compared with those values found on 98 denture teeth molds of five different brands; WC mean values for both males (54.1 $\mathrm{mm})$ and females $(52.1 \mathrm{~mm})$ were higher than the most frequent molds of denture teeth that were observed within 46-49 $\mathrm{mm}$ and followed by $42-45 \mathrm{~mm}$. In our study, most denture teeth molds were found within $50-51 \mathrm{~mm}$ and followed by $48-49 \mathrm{~mm}$, which are more in line with female teeth ratios.
Although this study emphasized the variation of teeth dimensions in function of gender and different denture teeth molds, particular ethnic/demographic characteristics and denture molds commercially available in different locations must be taken into account for distinct clinical situations. In addition, some denture teeth molds presented widths and lengths not observed in the population under study and thus are found to be useless. These findings may help dentists to better select denture teeth for oral rehabilitations with dimensions similar to natural teeth.

\section{CONLUSION}

Dentists must assume that males present wider and longer maxillary anterior teeth than females. All denture teeth presented dimensions compatible with natural teeth; however, the widest variety of molds is better matched to females. Denture central incisors are usually 0.5 to $1.5 \mathrm{~mm}$ shorter than the majority of natural teeth; in addition, some commercially available denture teeth present dimensions not observed in natural teeth (shorter than $8.6 \mathrm{~mm}$ and longer than $12 \mathrm{~mm}$ ).

\section{Acknowledgments}

The authors do not have any financial interest in the companies/products discussed in this study. This investigation was conducted at the Federal University of Goiás and supported by the Brazilian Agency for Support and Evaluation of Graduate Education - CAPES (grant \#DS1212378).

\section{Collaborators}

TORRES ÉM and NEVES RG, advised, designed, revised the theoretical assumptions and wrote the paper and documentation, preparation of figures. SOUZA DR, DAHER MRG, LIMA VHR participated in study design, data collection, analysis and writing of the manuscript. All authors reviewed the text and approved its final version.

\section{REFERENCES}

1. Srivastava R. Denture tooth selection: size matching of natural anterior tooth width with denture denture teeth. Int J Dent Clin. 2010;2:17-22.

2. Gomes VL, Gonçalves LC, do Prado CJ, Junior IL, de Lima LB. Correlation between facial measurements and the mesiodistal 
width of the maxillary anterior teeth. J Esthet Restor Dent. 2006;18(4):196-205. http://dx.doi.org/10.1111/j.1708-8240. 2006.00019_1.x

3. Mavroskoufis F, Ritchie GM. Nasal width and incisive papilla as guides for the selection and arrangement of maxillary anterior teeth. J Prosthet Dent. 1981;45(6):592-7. http:// dx.doi.org/10.1016/0022-3913(81)90417-0

4. Strajnić L, Vuletić I, Vucinić P. The significance of biometric parameters in determining anterior teeth width. Vojnosanit. Pregl. 2013;70(7):653-9. http://dx.doi.org/10.2298/vsp13076 $53 \mathrm{~s}$

5. Hoffman W, Bomberg TJ, Hatch RA. Interalar width as a guide in denture tooth selection. J Prosthet Dent. 1986;55(2):219-21. http://dx.doi.org/10.1016/0022-3913(86)90348-3

6. Duarte JR S, Schnider P, Lorezon AP. The importance of width/ length ratios of maxillary anterior permanent teeth in esthetic rehabilitation. Eur J Esthet Dent. 2008;3(3):224-34.

7. Krajicek DD. Natural appearance for the individual denture patient. J Prosthet Dent. 1960;10:205-14.

8. Varjão FM, Nogueira SS. Correlating the curve distance between the distal of the canines to the combined width of the six anterior teeth when selecting denture teeth for different ethnic groups. J Prosthet Dent. 2012;107(6):400-4. http://dx.doi.org/10.1016/S0022-3913(12)60099-7

9. Baker PS, Morris WJ, Lefebvre CA, Price G A, Looney SW. Relationship of denture cast measurements to width of maxillary anterior teeth. J Prosthet Dent. 2011;105(1):44-50. http://dx.doi.org/ 10.1016/S0022-3913(10)60190-4

10. Mahmood Z, Yazdanie N, Mumtaz F, Iqbal Z. Comparison of maxillary anterior teeth width in natural and denture dentition. Biomedica. 2011;27:641-3.

11. Magne P, Gallucci GO, Belser UC. Anatomic crown width/ length ratios of unworn and worn maxillary teeth in white subjects. J Prosthet Dent. 2003;89(5):453-61. http://dx.doi. org/10.1016/S0022-3913(03)00125-2

12. Al Wazzan KA. The relationship between intercanthal dimension and the widths of maxillary anterior teeth. J Prosthet Dent. 2001;86(6):608-12. http://dx.doi.org/10.1067/ mpr.2001.119682

13. Baer ML, Reynolds M A. Comparison of anterior tooth width in natural and denture dentitions. J Prosthodont. 1992; 1:847. https://doi.org/10.1111/j.1532-849X.1992.tb00435.x

14. Zagar M, KnezovićZlatarić D. Influence of esthetic dental and facial measurements on the Caucasian patients' satisfaction. J Esthet Restor Dent. 2011;23(1):12-20. http://dx.doi.org/10. $1111 / j .1708-8240.2010 .00381 . x$

15. Zlatarić DK, Kristek E, Celebić A. Analysis of width/length ratios of normal clinical crowns of the maxillary anterior dentition: correlation between dental proportions and facial measurements. Int J Prosthodont. 2007;20(3):313-5.

16. Owens EG, Goodacre CJ, Loh PL, Hanke G, Okamura M, Jo KH, et al. A multicenter interracial study of facial appearance. Part 1: A comparison of extraoral parameters. Int J Prosthodont. 2002;15(3):273-82.

17. Condon M, Bready M, Quinn F, O'Connell BC, Houston FJ, O'Sullivan M. Maxillary anterior tooth dimensions and proportions in an Irish young adult population. J Oral Rehabil. 2011;38(7):501-8. http://dx.doi.org/10.1111/j.1365-2842.20 10.02181.x.

18. Gillen RJ, Schwartz RS, Hilton TJ, Evans DB. An analysis of selected normative tooth proportions. Int J Prosthodont. 1994;7(5):410-7. 